\title{
Watershed level analysis of sediment filling in a Mexican highland reservoir
}

\author{
Juan Antonio García-Aragón ${ }^{1, *}$, Emmanuelle Quentin ${ }^{1,2}$, Carlos Díaz-Delgado ${ }^{1,3}$ and James \\ R. Hunt ${ }^{4}$ \\ 1 Centro Interamericano de Recursos del Agua-FI-UAEM, Cerro de Coatepec, CU, Toluca, México, CP:50130. \\ 2 equentin@uaemex.mx \\ 3 cdiaz@uaemex.mx \\ 4 Department of Civil and Environmental Engineering, 779 Davis Hall, University of California, Berkeley, USA. \\ 94720-1710. hunt@ce.berkeley.edu
}

*Corresponding author: jgarcia@uaemex.mx

\begin{abstract}
Watershed level analysis of sediment filling in a Mexican highland reservoir

The Upper Lerma River Basin (ULRB) in Mexico, with a watershed area of $2118 \mathrm{~km}^{2}$, is strongly affected by urbanization and deforestation. More than 1.5 million people and more than 2000 industries are located within it (INEGI, 2000). Furthermore, the basin topography is abrupt with levels ranging from 2560 to 4570 m.a.s.l. and its precipitation varies from $700 \mathrm{~mm}$ in the lower basin to $1200 \mathrm{~mm}$ at higher levels. The erosion produced by climactic and anthropic effects is concentrated in the José Antonio Alzate Reservoir, which is located at the basin outlet and captures all the waters of the ULRB. The basin, which had an initial capacity of $45 \mathrm{hm}^{3}$, has lost much of its capacity in only 42 years as is demonstrated here. Presented in this paper are the results from an erosion model using the RUSLE (Revised Universal Soil Loss Equation) methodology, which allows for the identification of critical areas. The resulting model is capable of explaining the high rate of sediment contribution. With the intention of validating the model, a bathymetric study of the reservoir was performed. .Actual bottom reservoir levels were compared with the levels before dam construction. This process was made with a GIS using a re-sampling process. The results show that reservoir storage capacity has been reduced by $21 \mathrm{hm}^{3}$ which makes difficult the irrigation and flood control functions of the reservoir. Selective removal of sediments will lead to benefits in pollutant removal in the reservoir and improved capacity for downstream irrigation supply and flood control.
\end{abstract}

Key words: Sediment filling, reservoir, erosion, bathymetry, sediment removal, deforestation, water quality.

\section{RESUMEN}

Análisis a nivel de cuenca del aterramiento en un embalse de montaña Mejicano

La cuenca Alta del río Lerma (CARL) en el Estado de México con una extensión de $2118 \mathrm{~km}^{2}$, se encuentra fuertemente afectada por la urbanización y la deforestación. En efecto, allí se asientan más de 1.5 millones de habitantes y más de 2000 industrias (INEGI, 2000). Adicionalmente la topografía de la cuenca es bastante abrupta con elevaciones desde 4570 m.s.n.m. hasta 2560 m.s.n.m. y su régimen pluvial varía de promedios anuales en las zonas altas de $1200 \mathrm{~mm}$ a $700 \mathrm{~mm}$ en las zonas bajas. La erosión producida por efectos climáticos y antrópicos se refleja en el embalse José Antonio Alzate el primero sobre el río Lerma y que capta todas las aguas de la CARL. El embalse con un capacidad de almacenamiento al construirse de 45 $\mathrm{hm}^{3}$ ha perdido mucha capacidad en tan solo 42 años de vida como se demuestra en este trabajo. Se presentan los resultados de un modelo de erosión de la cuenca utilizando el método RUSLE, lo cual permitió identificar las áreas críticas. El modelo resultante es capaz de explicar la alta tasa de aporte de sedimentos. Con el fin de validar el modelo se efectúo un levantamiento batimétrico del embalse. La topografía actual se comparó con la existente antes de la construcción de la cortina. Este proceso de acoplamiento fue realizado en un SIG con base en un proceso de remuestreo. Los resultados muestran una reducción en la capacidad del embalse de $21 \mathrm{hm}^{3}$ lo cual le impide cumplir adecuadamente con sus funciones de irrigación y control de inundaciones. Una remoción selectiva de sedimentos es propuesta en este artículo procurando incrementar la eficiencia de remoción de contaminantes del embalse y la capacidad para el control de inundaciones y suministro de agua para irrigación.

Palabras clave: Aterramiento, embalse, erosión, batimetría, remoción de sedimentos, deforestación, calidad del agua. 


\section{INTRODUCTION}

The upper basin of the Lerma River is located in central Mexico adjacent to the Mexico City valley (Fig. 1). Recently, particularly after the Mexico City 1985 earthquake, the basin has increased its population by $150 \%$, to 1.5 millions people (INEGI, 2000). There is great pressure within the basin to further utilize the scarce natural resources of land, forests, and water. The upper lands of the basin were originally forested but the forests are now disappearing even within designated national parks. Deforestation has increased sediment loss because of the steep slopes and intense rainfall. The abrupt relief, with elevations in the Toluca volcano of 4570 m.a.s.l. and $2560 \mathrm{~m}$. a.s.l., in the lower basin contributes to the erosion process.

Rainfall variation in the basin is shown in figure 2 and closely follows the topography. Precipitation is over $1200 \mathrm{~mm} / \mathrm{year}$ near the Toluca volcano and about $700 \mathrm{~mm} / \mathrm{yr}$ in the lower basin. As it is typical of central Mexico, precipitation is dominated by summer rains and dry winters. The Lerma River was dammed at the downstream end of the Upper Basin in 1959 with the José Antonio Alzate Reservoir utilized for flood control and spring irrigation in the downstream basin. At the time of reservoir completion, Toluca City had a small population of 200000 inhabitants with an economy based on farming and governmental services. Groundwater from the basin has been exported at a rate of $5 \mathrm{~m}^{3} / \mathrm{s}$ to Mexico City as a supplemental water supply from 1953 to date. With population growth in Toluca and in the surrounding basin following the Mexico City earthquake of 1985, human and industrial waste has exceeded the capacities of treatment plants, and the Lerma River, flowing into the Alzate Reservoir is high in organic matter and metals, and devoid of oxygen (Barceló et al., 2000).

This paper quantifies the soil erosion using the Revised Universal Soil Loss equation RUSLE (Renard et al. 1991) and sediment accumulation within the reservoir with the resulting loss of reservoir capacity. Soil loss prevention strategies are considered in the upper lands along with an analysis on how dredging sediment from the reservoir will benefit flood control, increase the irrigation supply, and improve water quality.

\section{METHODOLOGY}

\section{Basin erosion}

A LANDSAT-TM satellite scene covering the ULRB was used in order to classify the land cover. Most of the agriculture in the basin is corn, thus we defined the land use coefficients for cultivated lands according to data relating

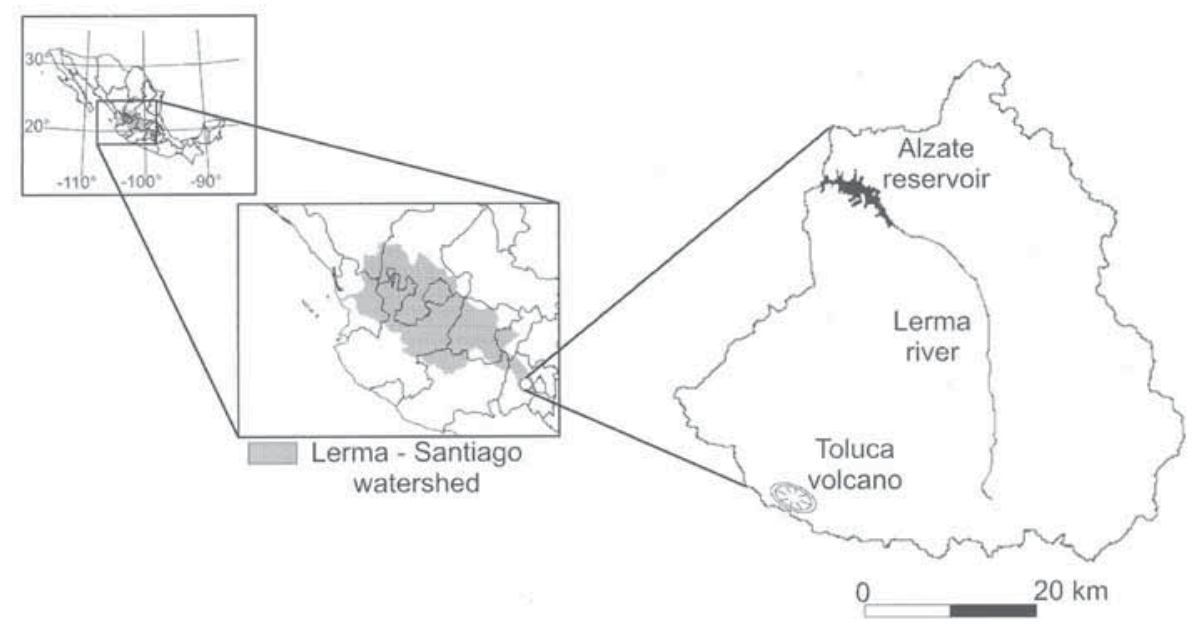

Figure 1. Upper Lerma river basin (ULRB). Cuenca Alta del río Lerma (CARL). 


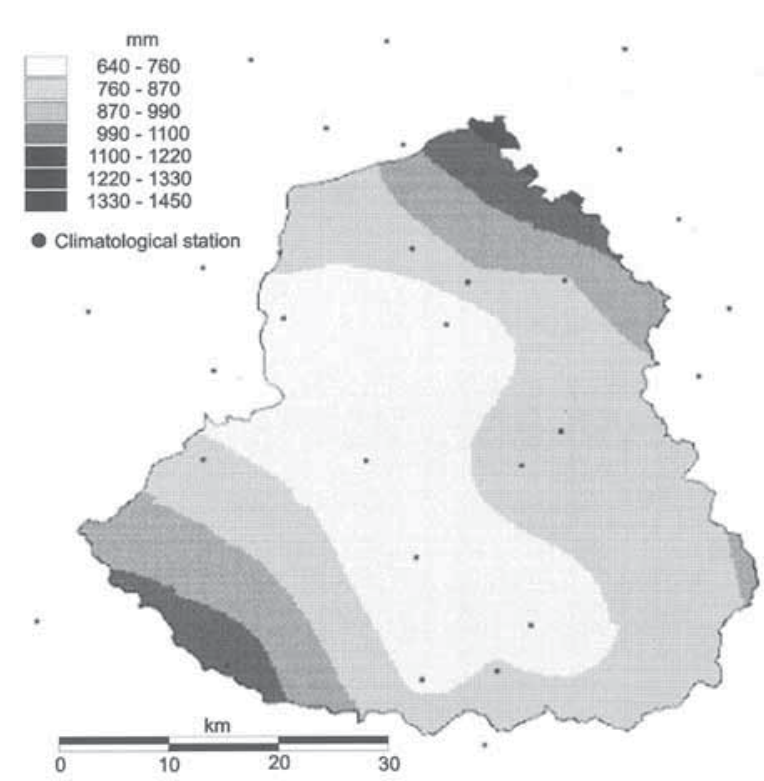

Figure 2. Annual mean precipitation in ULRB, with dots indicating the location of precipitation records. Precipitación media anual en la CARL, con puntos indicando estaciones de precipitación.

to corn. Lands devoted to grass, forest areas, wetlands, and urban areas were also defined. Land use factor $C$ into the RUSLE methodology is presented in figure 3. The largest value, $C=0.25$ is related to agriculture.

To define the erosivity index $R, 26$ climatologic stations located inside or close to the basin

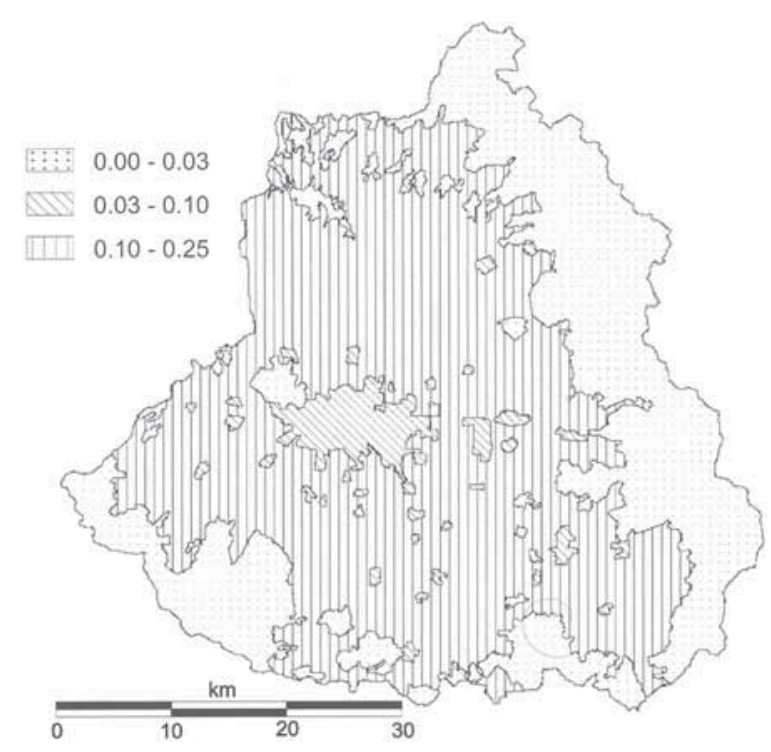

Figure 3. Land use factor C in ULRB. Factor de uso de suelo C en la CARL

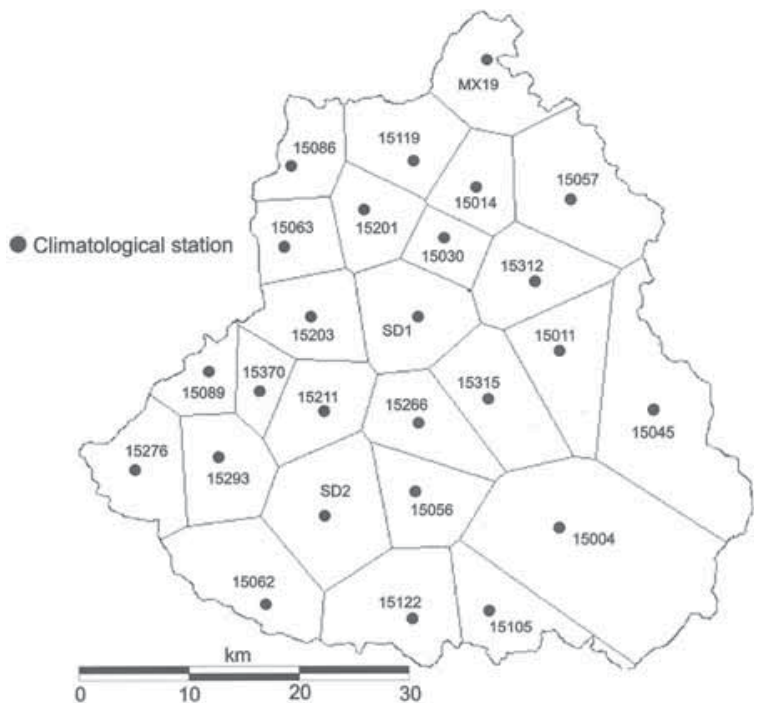

Figure 4. IDs of Thiessen polygons in the ULRB. Identifcación de los polígonos de Thiessen en la CARL.

were analysed. From the whole record, a mean of 30 minutes rainfall intensity was obtained for each station and the following formula, proposed by Wischmeier (1978), was applied.

$$
R=\frac{\left[\sum_{j=1}^{n}\left(1.213+0.890 \log _{10} I_{j}\right)\left(I_{j} T_{j}\right)\right] I_{30}}{173.60}
$$

where $R$ is the erosivity index $(M J * m m /(h a * h r)$, $I_{j}$ is the 60 minutes rain intensity for the $j$ storm $(\mathrm{mm} / \mathrm{hr}), T_{j}$ is the duration of $j$ storm (hr), $I_{30}$ is the mean intensity in 30 minutes $(\mathrm{mm} / \mathrm{hr}), j$ is the storm index, and $n$ is the number of storms.

Then, an average $R$ value was calculated for each climatologic station and using the method of Thiessen polygons, a value of $R$ was assigned to each polygon area. The distribution and ID of Thiessen polygons in the ULRB are shown in figure 4. Table 1 shows the $R$ values calculated at each station and the corresponding Thiessen polygon area. The larger values, as expected, are found near the boundaries of the basin where elevations and precipitation are high.

\section{Bathymetric study}

In order to define the existing bottom levels of the reservoir a bathymetric analysis was 
Table 1. $\mathrm{R}$ values assigned to Thiessen polygons. Valores de R asignados a los polígonos de Thiessen.

\begin{tabular}{|c|c|c|c|c|}
\hline ID & STATION NAME & BASIN AREA $\left(\mathrm{Km}^{2}\right)$ & $\%$ & R MJ*mm/(ha*hr) \\
\hline 15004 & Almoloya del Río & 254.0 & 12.0 & 90.0 \\
\hline 15011 & Atarasquillo & 84.7 & 4.00 & 82.1 \\
\hline 15203 & Calixtlahuaca & 61.1 & 2.88 & 72.2 \\
\hline 15014 & Capulhuac & 52.0 & 2.46 & 130.5 \\
\hline MX19 & Cerro de la Catedral & 75.3 & 3.56 & 130.5 \\
\hline 15266 & CNA Gerencia Toluca & 69.9 & 3.30 & 78.2 \\
\hline 15312 & Colonia Álvaro Obregón & 74.1 & 3.50 & 79.2 \\
\hline 15315 & EPCCA & 86.2 & 4.07 & 117.2 \\
\hline 15370 & Observatorio C.N.A. & 32.2 & 1.52 & 51.2 \\
\hline 15030 & Hacienda de La "Y" & 35.8 & 1.69 & 115.8 \\
\hline 15045 & La Marquesa & 163.9 & 7.74 & 150.4 \\
\hline 15229 & Loma Alta & 42.6 & 2.01 & 44.5 \\
\hline 15056 & Mexicalcingo & 64.7 & 3.05 & 82.9 \\
\hline 15057 & Mimiapan & 117.2 & 5.54 & 98.6 \\
\hline 15062 & Nevado de Toluca & 81.4 & 3.85 & 111.6 \\
\hline 15211 & Nueva Oxtotitlán & 64.4 & 2.99 & 59.7 \\
\hline 15063 & Nueva Santa Elena & 48.5 & 2.29 & 76.7 \\
\hline 15086 & San Bernabé & 54.5 & 2.57 & 82.3 \\
\hline 15089 & San Francisco T. & 36.9 & 1.75 & 82.6 \\
\hline 15276 & San José El Contadero & 51.3 & 2.42 & 36.3 \\
\hline 15293 & San Juan de las Huertas & 62.8 & 2.97 & 75.2 \\
\hline 15211 & Temoaya & 89.8 & 4.24 & 98.3 \\
\hline 15201 & Las Trojes & 54.9 & 2.59 & 98.0 \\
\hline SD1 & Santín & 81.9 & 3.87 & 100.0 \\
\hline $\mathrm{SD} 2$ & Zacango & 105.3 & 4.97 & 75.0 \\
\hline 15105 & San Pedro Techuchulco & 74.9 & 3.54 & 86.6 \\
\hline \multirow[t]{2}{*}{15122} & Tenango del Valle & 97.5 & 4.60 & 83.6 \\
\hline & Total & 2117.9 & 100.00 & \\
\hline
\end{tabular}

developed. It was performed during the season when the reservoir is at lower water levels (AprilJuly) after the peak irrigation period (FebruaryMarch) and before the heavy rains. The technique used was a geo-referenced open polygon and random points that covered the whole reservoir. In the lower reservoir, boats equipped with depth soundings were used. The new levels were compared with the original topography before dam construction in 1959. The comparison was performed with the GIS Idrisi (Eastman, 2006). It was necessary to perform a difficult process of geographical location and coupling of layers because of the time delay between topographies. The 1959 topography (1:20000 scale) was made with geometric coordinates instead of geographic ones. The coupling process was performed within the Idrisi package using the resample tool and the 
aid of satellite images and INEGI (1970) digital cartography 1:50000 scale.

A re-sampling of the 1959 vectorial curves was necessary to geo-reference the data obtained in an unknown plane reference system. It should be based on mathematical expectation estimates of the selected concomitance morphological key points with other geo-referenced digital maps. Then for each vectorial set (1959 and 2004), both at 1 meter contour interval, an inter-contour lineal interpolation was applied to generate the digital elevation models (DEM) choosing a cell resolution of 10 by 10 meters. The results of the resample process applied to the bathymetric layers was obtained with a confidence level of $90 \%$ (i.e. $Q=0.1$ ) considering an acceptable error on the ground of $50 \mathrm{~m}$. This is due to the non geo-referenced historical topographic maps.

\section{RESULTS}

The results of the erosion analysis were obtained for sub-basins of the ULRB. Some sub-basins were not easy to define because of the complex drainage networks in urban areas. Some storm water collectors divert water from one sub-basin to another. Figure 5 shows the sub-basins and the predicted soil loss in ton/ha/year. Figure 5

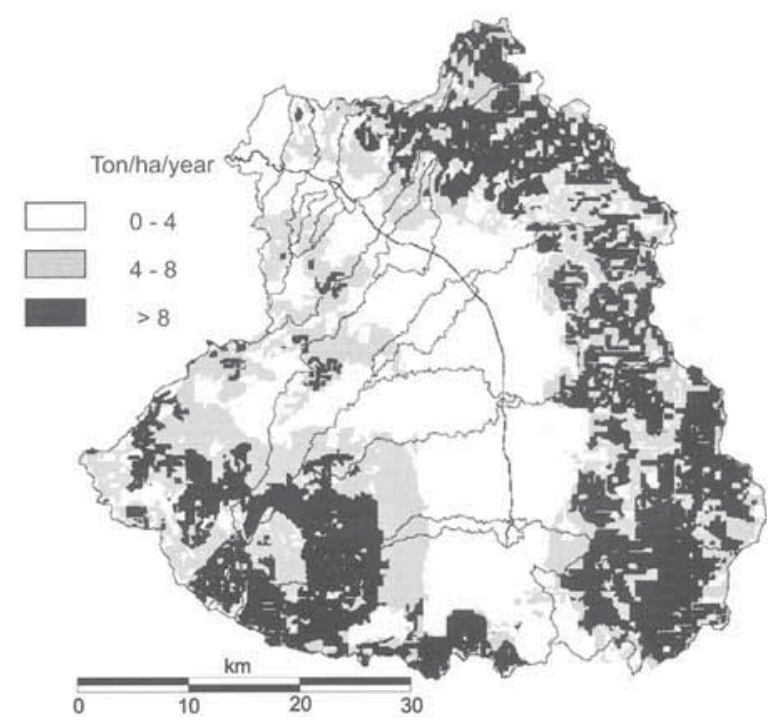

Figure 5. Soil loss in ton/ha/year. Pérdida de suelo en ton/ha/año.

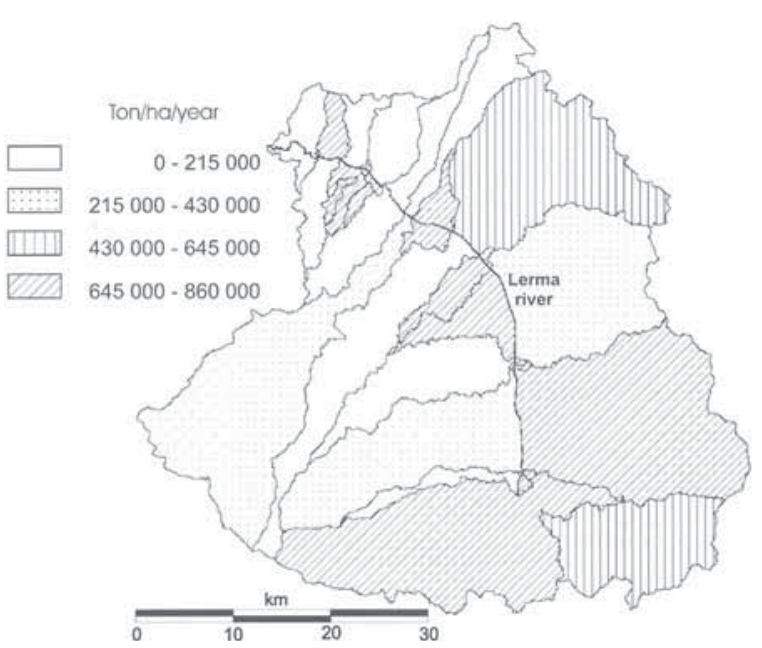

Figure 6. Soil loss in each sub-basin (ton/year). Pérdida de suelo en cada sub-cuenca (ton/año).

also shows that most of the soil loss is near the boundaries of the basin, which corresponds to higher slopes as will be shown later.

Figure 6 shows the soil loss in each subbasin. It shows that sub-basins around the Toluca Volcano and higher lands contribute to more than $60 \%$ of the total soil loss in the basin.

Table 2 shows quantitatively the loss in each sub-basin. To better understand Table 2, figure 7 shows the ID of each sub-basin. To

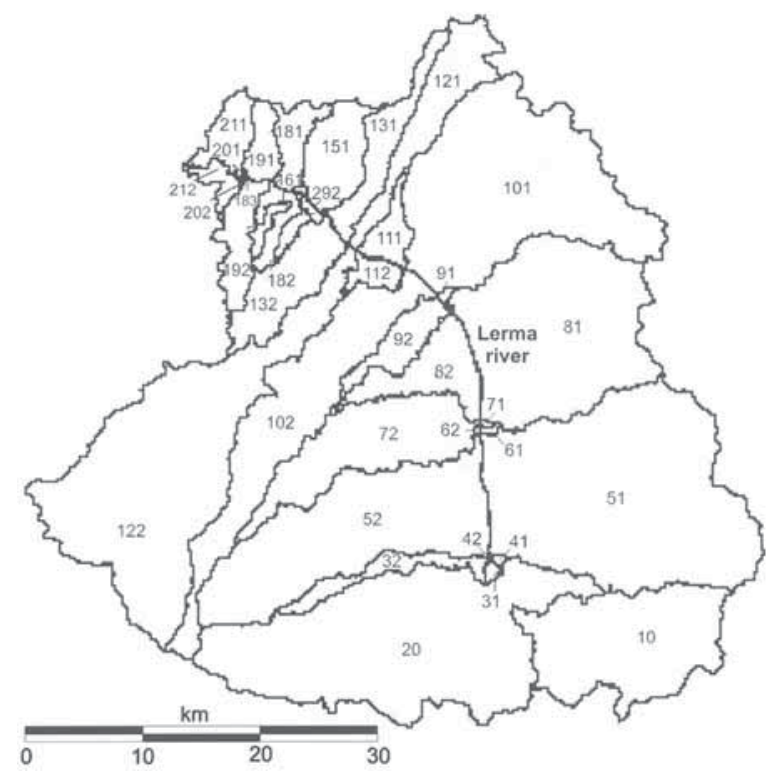

Figure 7. IDs per sub-basin of ULRB. ID por cada subcuenca CARL. 
Table 2. Soil loss per year in each sub-basin of the ULRB. Pérdida de suelo por año en cada sub-cuenca de la CARL.

\begin{tabular}{|c|c|c|c|c|}
\hline Sub.basin name & ID right & ton/year & ID left & ton/year \\
\hline East Almoloya del Río & 10 & 635000 & & \\
\hline Nort Almoloya del Río & & & 20 & 850000 \\
\hline Bridge over Toluca-Santiago & 31 & 140 & 32 & 33400 \\
\hline Mezapa stream & 41 & 51 & 42 & 6 \\
\hline San Mateo & 51 & 854000 & 52 & 215600 \\
\hline Bridge México-Toluca & 61 & 83 & 62 & 10 \\
\hline Reciclagua & 71 & 26 & 72 & 40200 \\
\hline Totoltepec & 81 & 315200 & 82 & 5220 \\
\hline Bridge Toluca-Naucalpan & 91 & 92 & 92 & 4040 \\
\hline Toluca-Norte treatment plant & 101 & 623400 & 102 & 142300 \\
\hline Road Toluca-Temoaya & 111 & 7120 & 112 & 950 \\
\hline Entrance Alzate reservoir & 121 & 146800 & 122 & 354600 \\
\hline Zone A Alzate reservoir & 131 & 87500 & 132 & 23000 \\
\hline Zona C Alzate reservoir & 151 & 39900 & 152 & 60 \\
\hline Zona D Alzate reservoir & 161 & 30 & 162 & 3 \\
\hline Zona F Alzate reservoir & 181 & 11360 & 182 & 3400 \\
\hline Alzate reservoir spillway & 191 & 7240 & 192 & 11140 \\
\hline Downstream bottom outlet & 201 & 4 & & \\
\hline Bridge Toluca-Atlacomulco & 211 & 10 & & \\
\hline Total per lerma river side (ton) & & 2727800 & & 1683500 \\
\hline Basin total (ton) & & & & 411300 \\
\hline
\end{tabular}

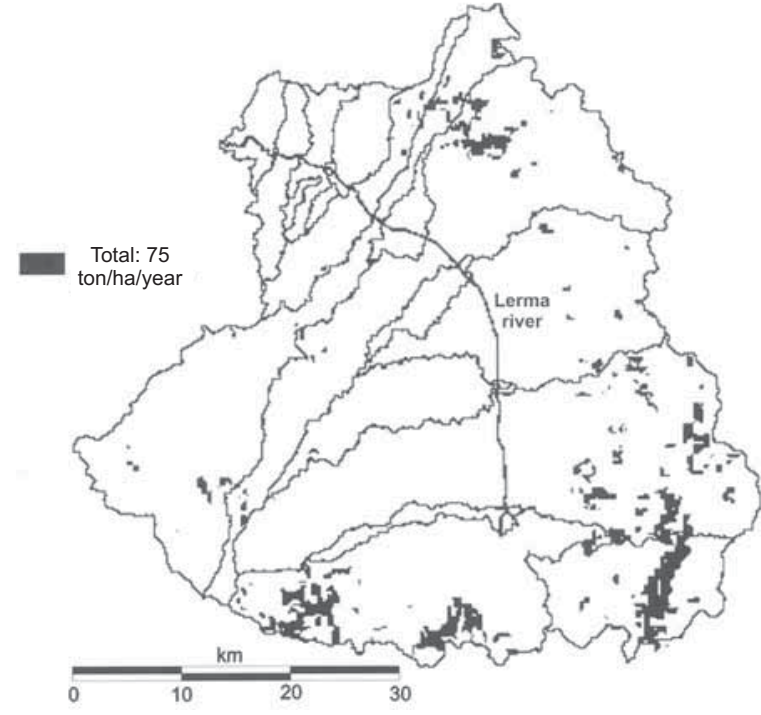

Figure 8. Areas with an erosion rate greater than 75 ton/ha/year, in the ULRB. Áreas de erosión mayor a 75 ton/ha/año en la CARL. define critical areas of erosion a threshold of 75 ton/ha/year was defined. Figure 8 shows the areas with soil loss larger than the defined threshold. Figure 8 clearly shows that critical erosion areas correspond to zones recently deforested, because they are at the boundaries of the forested area. The highlighted areas in figure 8 represent less than $12 \%$ of the ULRB basin, but generate $50 \%$ of the total soil loss of the basin (2 200000 ton or $830000 \mathrm{~m}^{3}$, considering an average sediment density of $2.65 \mathrm{ton} / \mathrm{m}^{3}$ ).

From the comparison of the 1959 and 2004 topographies the reservoir capacity vs. levels for each period were obtained (Fig. 9). Then a matrix subtraction, performed with the aid of GIS, between both topographies produced the deposited sediment volumes for the whole reservoir. Those results are presented in figure 10 where three main deposit areas are shown 
in circles. Near the dam, recently deposited sediment reached more than 8 meters in depth. The volume of deposited sediments during the 42 years of reservoir life was calculated at $21 \mathrm{hm}^{3}$ (Figure 9), which represents an average annual sediment inflow of $500000 \mathrm{~m}^{3}$.

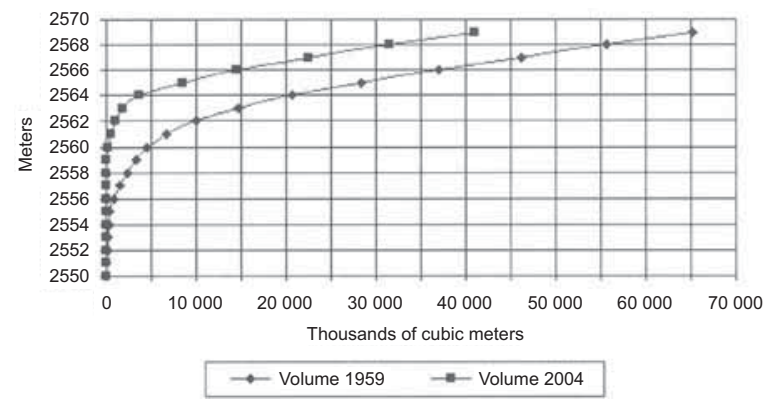

Figure 9. Comparison of the Alzate Reservoir's capacities in 1959 and 2004. Comparación de capacidades del embalse Alzate en 1959 y 2004.

\section{DISCUSSION}

The sediment filling in the Alzate Reservoir is threatening its functions. The calculated loss of $21 \mathrm{hm}^{3}$ in reservoir capacity compromises reservoir operation at lower levels. For reservoir levels below 2564 m.a.s.l. the reservoir is not effective for use in water supply. Additionally, when the reservoir is full, there is no additional capacity for flood mitigation and the reservoir acts as a run of the river reservoir. In addition, the reduced volume limits the pollutant removal efficiency since the residence time is half its normal time. To restore at least part of its capacity at lower levels is an urgently needed measure.

In addition, the sediment influx will continue in the future. If there no actions are taken in the upper lands, an estimate of $375000 \mathrm{~m}^{3}$ (75\% of average annual soil loss in ULRB after considering trap efficiency of the reservoir,

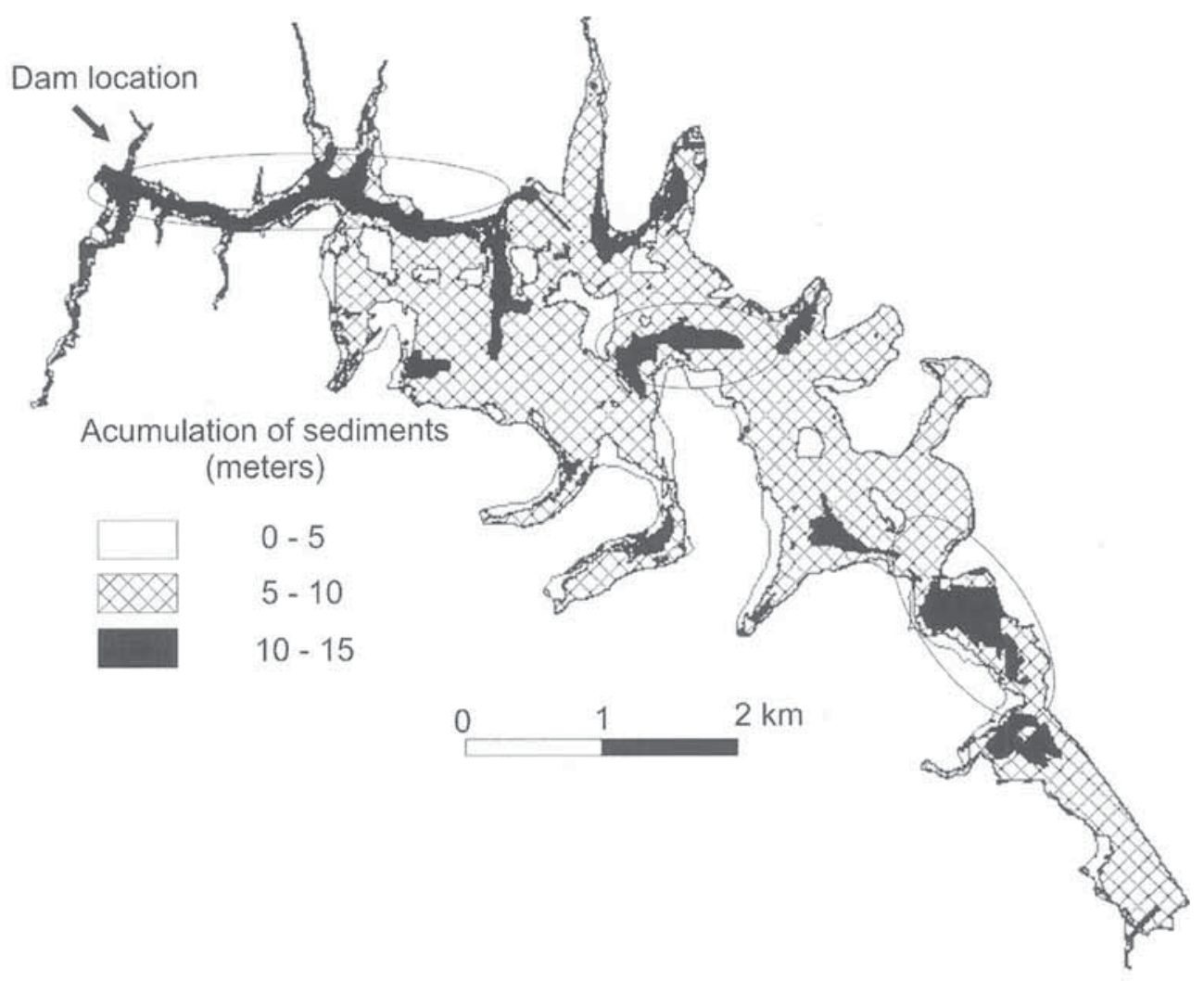

Figure 10. Deposited sediment columns in the Alzate Reservoir. Columnas de sedimento depositadas en el embalse Alzate. 
Garcia Aragon et al., 2003) will be deposited in the reservoir each year. A further increase in sediment depth could be catastrophic for upstream settlers. Each year the town of San Mateo Atenco, $25 \mathrm{~km}$ upstream of the reservoir, is flooded because of the back water curve generated by the reservoir.

The average annual rate of sediment filling in the reservoir seems low compared to the average annual basin soil loss calculated. It should be emphasized that the results in soil loss provided by RUSLE depict the land use situation at the year 2000 corresponding to the date of the satellite image. It is certain that the soil loss has changed during the life of the reservoir, probably during the two recent decades. From 1985 the annual soil loss is larger than in previous decades. If this is true, soil production (amount of sediments reaching the Alzate Reservoir) should have increased and the sediment delivery ratio SDR (soil production/soil loss) should be larger in recent decades than before.

The reservoir can provide downstream benefits as a stabilization pond if a minimum volume is maintained. The mean Biological Oxygen Demand (BOD), during the dry months, at the reservoir entrance $\left(\mathrm{BOD}_{\text {in }}\right)$ is $200 \mathrm{mg} / \mathrm{L}$ (Barceló, 2000) and with a reasonable removal efficiency a BOD concentration at the outlet $\left(B O D_{\text {out }}\right)$ is expected to be $60 \mathrm{mg} / \mathrm{L}$. The mean water inflow $(Q)$ into the reservoir is $432,000 \mathrm{~m}^{3} /$ day $\left(5 \mathrm{~m}^{3} / \mathrm{s}\right)$ (Hunt et al., 2000). If a facultative pond, working as a well mixed reactor, is designed at the entrance of the reservoir with a mean depth $(D)$ of $4 \mathrm{~m}$ and a decay factor $K$ of $0.2351 /$ day, then Ladegaard \& Johenssen (2001) suggest a prediction model for the required reservoir area, $A$, as,

$$
A=\frac{Q}{D K}\left(\frac{B O D_{\text {in }}}{B O D_{\text {out }}-1}\right)
$$

According to this equation (2), the required pond area $(A)$ is $1,050,000 \mathrm{~m}^{2}$, that for a $4 \mathrm{~m}$ average depth represents a reservoir volume of $4200000 \mathrm{~m}^{3}$.
The latter calculations assume a lower residence time for the dry months. Because the average flow rate during dry months is between $0.6 \mathrm{~m}^{3} / \mathrm{s}$ and $1.5 \mathrm{~m}^{3} / \mathrm{s}$, the former pond area calculation has a safety factor which is useful considering the predictable future sediment filling of the pond.

The volume calculated can be dredged from the reservoir entrance up to the first restriction (Figure 10), where 4 to $7 \mathrm{~m}$ of sediments have been accumulated since the reservoir was constructed. The pond would have a small dam separating it from the downstream reservoir to maintain its depth, and will operate as a sediment trap that would be easier to clean out than the whole reservoir. The resulting pond has a length of $3.5 \mathrm{~km}$, a width of $300 \mathrm{~m}$, and a depth of $4 \mathrm{~m}$.

The proposed sediment removal basin will ensure the pollutant removal efficiency of the reservoir. However, if there are no actions in the upper elevations of the watershed, the constructed pond will silt in a short period of time. The latter action should be made in conjunction with reforestation in the critical areas previously defined. As an example of the reforestation benefits, if the soil loss in those critical areas $\left(250 \mathrm{~km}^{2}\right)$ is avoided, the silting of the reservoir will decrease to $187,5 \mathrm{~m}^{3} /$ year and the useful life of the proposed basin will double.

Finally, water resource engineering has always involved the identification of multiple objectives for large scale projects. The Upper Lerma River Basin has undergone significant changes since the original reservoir was constructed and its operational procedures established. Increased sedimentation was not anticipated and now threatens the historical operation of the system and the potential use as a stabilization basin for water quality improvement. Reservoir dredging to increase capacity has multiple justifications, but the implementation of such a potentially expensive approach should be undertaken in conjunction with reduced erosion in upland areas. Sediment sources have been identified and a comprehensive approach to continued water resource development has been outlined through modelling and field scale measurements. 


\section{REFERENCES}

BARCELÓ QUINTAL, I., H. SOLIS CORREA, C. GONZALEZ, P. AVILA \& J. A. GARCÍA ARAGÓN.] 2000. Determination of Cadmium and Lead species in the water column of the J.A. Alzate reservoir, México. Water Environment Research, 72: 132-140.

BARCELÓ QUINTAL, I. 2000. Estudio de la movilidad de $\mathrm{Ca}, \mathrm{Cd}, \mathrm{Cu}, \mathrm{Fe}, \mathrm{Mn}, \mathrm{Pb}$ y Zn en sedimentos de la presa José Antonio Alzate en el Estado de México. Tesis para obtener el grado de doctor en Ingeniería, CIRA-FI-UAEM. Toluca, México. 212 pp.

EASTMAN, J. R. 2006. IDRISI Andes, Guide to GIS and image processing, Clark Labs, Clark University, Worcester, Massachusetts, USA, 328 pp.

GARCÍA-ARAGON, J. A., C. DÍAZ-DELGADO, P. MORALES, P. AVILA-PEREZ, S. TEJEDA y G. ZARAZÚA. 2003. Concentración de metales en sedimento y su relación con los patrones de deposición en la presa J. A. Alzate, Edo. de México. Ingeniería Hidráulica en México, XVIII (4): 59-71.

HUNT, J., J. A. GARCÍA ARAGÓN y C. DÍAZDELGADO. 2000. Un ejemplo de contaminación de aguas superficiales el Carl. In: Sequía en un mundo de agua. D. Anton, \& C. Díaz Delgado (eds.): 185-216. Piriguazú ediciones, Uruguay. ISBN 9974-7571-3-4.

INEGI. Instituto Nacional de Estadística, Geografía e Informática). 1970. Cartas temáticas INEGI, escala 1:50000 (E14A27, E14A37, E14A28 y E14A48), México.

INEGI. Instituto Nacional de Estadística, Geografía e Informática. 2000. Resultados del censo de población, México. 235 pp.

LADEGAARD, N. \& S. E. JØRGENSEN. 2001. Waste stabilization ponds and constructed wetlands design manual. Danish University of Pharmaceutical Sciences. Section of Environmental Chemistry. Copenhagen Denmark. 187 pp.

RENARD, K., G. FOSTER, G. WEESIES \& J. PORTER. 1991. RUSLE: Revised Universal Soil Loss Equation. Journal of Soil and Water Conservation. 46: 30-33.

WISCHMEIER, W. H. \& D. D. SMITH. 1978. Predicting Erosion Losses. A Guide to Conservation Planning, Agriculture Handbook n ${ }^{\circ}$ 537, USDA Washington, D. C. 156 pp. 